\title{
Grøftegraverfraktur på norsk
}

\author{
Grøftearbeidere og snøscooterførere kan ha mer til felles enn du tror.
}

Menneskets skjelett består av omtrent 206 knokler, som gir opphav til mange frakturtyper. Alle frakturer kan navngis og klassifiseres etter anatomisk lokalisasjon, men flere har også andre navn, inkludert eponymer, dvs. at de er oppkalt etter personer, ofte leger. Et eksempel er distal radiusfraktur som fikk sitt navn etter kirurgen Abraham Colles (1773-1843) (1) og som er blitt kalt Colles' fraktur siden 1800-tallet (2). Vi har også Smiths fraktur, Monteggias fraktur og Galleazzis fraktur bare i håndledd og underarm.

\section{Skademekanisme eller skadens utseende som navnegrunnlag}

En annen måte å navnsette skaden på er å beskrive skadens utseende, for eksempel tåredråpefraktur (i nakken) og bøttehankruptur (i menisken). Skademekanismen kan også gi opphav til navn på skader, slik det fremgår av en artikkel i dette nummer av Tidsskriftet (3). Francis Odeh \& Roar Kloster beskriver en pasient som ved en snøscooterulykke fikk flere isolerte frakturer i processus spinosi. Denne sjeldne frakturtypen - den gir kun 17 treff i PubMed - kalles gjerne «Clay-Shoveler's fracture» i engelskspråklig litteratur. Navnet kan umiddelbart se ut som et eponym, men det henviser til den vanligste skademekanismen i 1930årene (4). Da oppsto bruddene oftest som en yrkesskade hos arbeidere som skuffet tung leire ved grøftegraving i Australia eller under byggingen av motorveier i Tyskland. I litteraturen brukes også betegnelser som Schipperkrankheit, Schipper's disease, root pullers' disease og - hos unge pasienter Schmitt's disease (5).

\section{Norsk betegnelse}

Vi ønsket å finne en norsk oversettelse av clay-shoveler's fraktur som også kunne si noe om skademekanismen. Det språklige utgangspunktet er clay = leire og shoveler $=$ person eller ting som måker eller skyfler noe (6). Det er flere beskrivelser av mekanismen og felles for dem ser ut til å være at personen skuffer, graver opp eller lemper tung last og kaster den høyt over skulderen. Skaden oppstår når bevegelsen stanses brått (3), for eksempel når leiren henger fast i spaden. Vi diskuterte mange forslag som inneholdt ordet leire, slik som leiregraver-

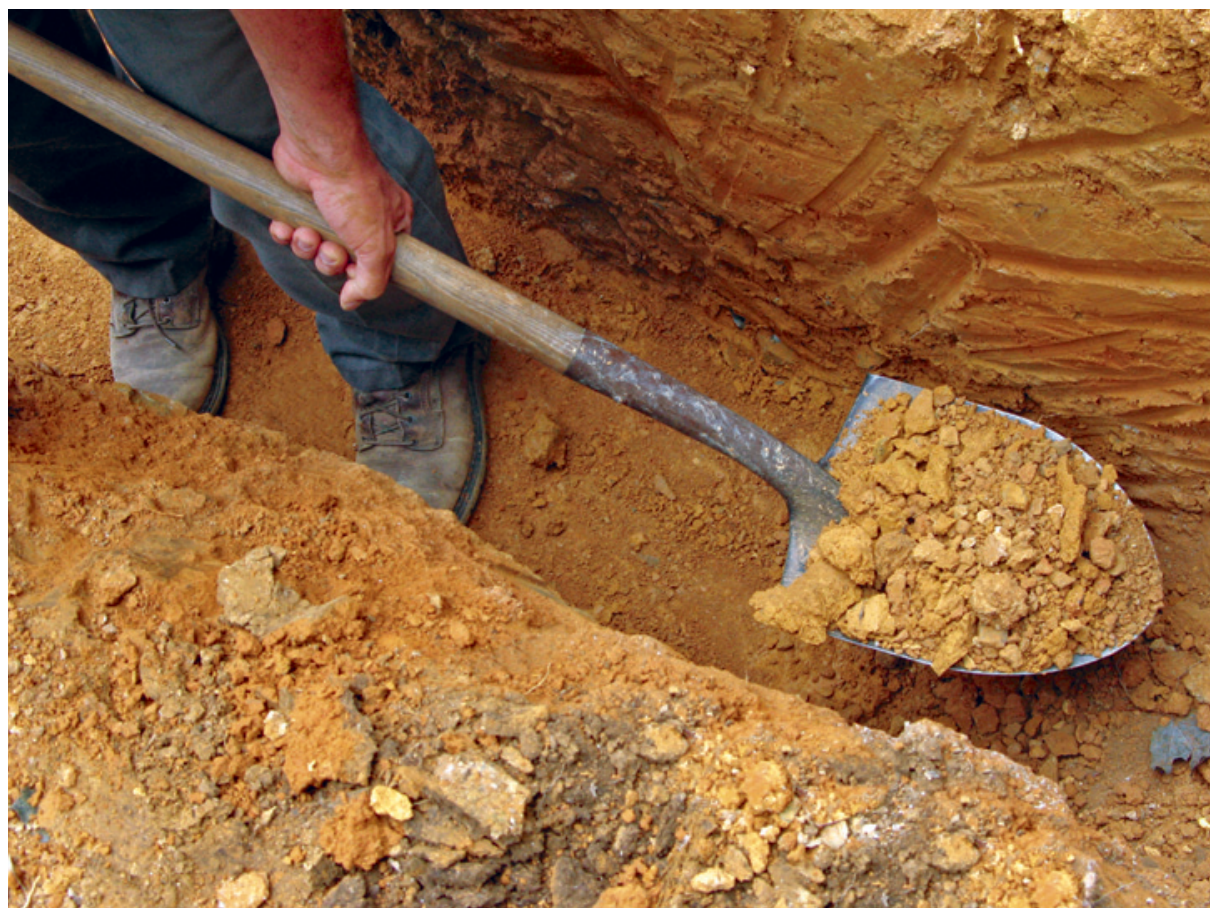

Illustrasjonsfoto Istockphoto

fraktur, leireskufferfraktur og leireskuflerfraktur, men slike sammensetninger virket litt fremmedartede. Vi endte til slutt med å foreslå grøftegraverfraktur som norsk betegnelse (3). Vi synes det er en rimelig oversettelse av det engelske opphavet, «grøftegraver» er et velkjent ord på norsk, og begrepet gir en god beskrivelse av den historiske skademekanismen.

\section{Merete Kile Holtermann}

merete.holtermann@legeforeningen.no

Petter Gjersvik

Erlend Hem

Tidsskriftet

Merete Kile Holtermann (f. 1982) er lege og medisinsk redaktør i Tidsskriftet.

Petter Gjersvik (f. 1952) er førsteamanuensis ved Oslo universitetssykehus, Rikshospitalet og medisinsk redaktør i Tidsskriftet.

Erlend Hem (f. 1970) er dr.med. og fungerende sjefredaktør i Tidsskriftet.
Litteratur

1. Colles' fraktur (Store medisinske leksikon). I: Store norske leksikon. http://snl.no/ $\mathrm{sml}$ artikkel/Colles\%26apos\%3B fraktur (18.12.2012).

2. Macdonald JA. On Colles' fracture of the radius and its treatment. Br Med J 1873; 1: 223-4. www.ncbi.nlm.nih.gov/pmc/articles/PMC2293420 (18.12.2012).

3. Odeh F, Kloster R. Grøftegraverfraktur. Tidsskr Nor Legeforen 2013; 133: 0000.

4. Hall RDM. Clay-Shoveler's fracture. J Bone Joint Surg Am 1940; 22: 63-75

5. Cancelmo JJ jr. Clay shoveler's fracture. A helpful diagnostic sign. Am J Roentgenol Radium Ther Nucl Med 1972; 115: 540-3.

6. Henriksen P. Haslerud VC, red. Engelsk stor ordbok. Oslo: Kunnskapsforlaget, 2001: 158, 932.

Mottatt 20.12. 2012 og godkjent 20.12. 2012. Medisinsk redaktør Raida Ødegaard. 